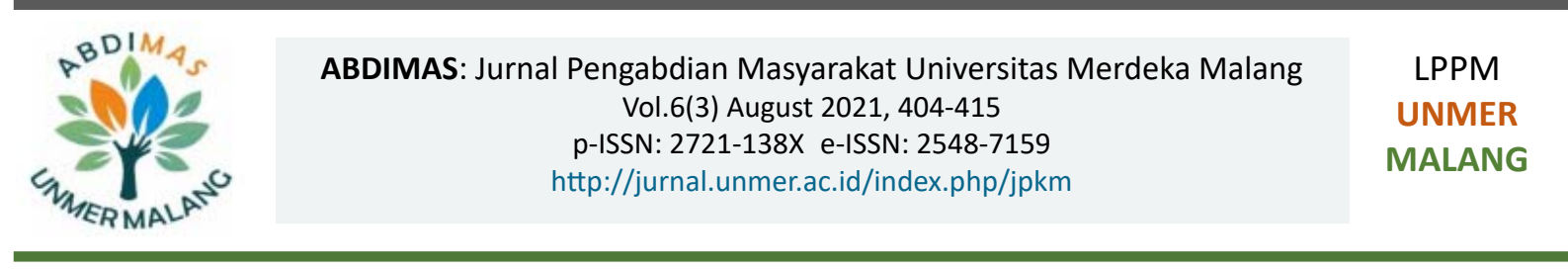

\title{
Gagasan Kampung Oksigen Pandanwangi sebagai Upaya Meningkatkan Kesadaran Masyarakat Peduli Lingkungan di Kota Malang
}

\author{
Aris Siswati ${ }^{1}$, Dani Yuniawan² \\ 'Departemen Ekonomi Pembangunan, Fakultas Ekonomi dan Bisnis, ${ }^{2}$ Departemen Teknik Industri, Fakultas Teknik \\ Universitas Merdeka Malang, Jl. Terusan Raya Dieng 62-64, Malang, 65146, Indonesia
}

\begin{abstract}
ARTICLE INFO
Received: 2019-05-24

Revised: 2019-10-19

Accepted: 2020-01-18

Keywords:

Grapevines, Kampung Oksigen, Malang, Sansevieria, Sustainability.

ABSTRACT

Population growth in Indonesia always increases every year. This has resulted in an increase in life support needs such as buildings, transportation and others. If it is not balanced with the concept of sustainable development, it will cause problems for the environment. Indicators of environmental problems caused by population growth in each region are always different. Malang City is one of the cities experiencing population growth. One indicator of environmental problems in the city of Malang is an increase in the number of sufferers of acute respiratory infections (ARI) every year. Pandanwangi Village is one of the villages with the highest ARI disease spread apart from Kedungkandang and Mulyorejo. The solution to overcome these environmental problems is by carrying out "Kampung Oksigen" Oxygen Village Planning in Pandanwangi Village. The concept of a "Kampung Oksigen" that is realized is by multiplying plants such as Sansevieria and grapevines that have the ability to produce oxygen and absorb carbon dioxide produced by vehicles. The result of this service is in the form of a "Kampung Oksigen" gate equipped with a set of supporting plants to be a pilot for community efforts to participate in creating a healthy and beautiful environment.
\end{abstract}

C)2021 Published by University of Merdeka Malang. This is an open access article distributed under the CC BY-SA 4.0 license (https://creativecommons.org/licenses/by-sa/4.0/)

How to cite: Siswati, A., \& Yuniawan, D. (2021). Gagasan Kampung Oksigen Pandanwangi sebagai Upaya Meningkatkan Kesadaran Masyarakat Peduli Lingkungan di Kota Malang. Abdimas: Jurnal Pengabdian Masyarakat Universitas Merdeka Malang, 6(3), 404-415. https://doi.org/10.26905/abdimas.v5i1.5585

\section{PENDAHULUAN}

Indonesia merupakan salah satu negara berkembang dengan jumlah penduduk yang mengalami peningkatan setiap tahunnya. Pada tahun 2020, jumlah penduduk Indonesia diperkirakan akan mencapai 270 juta jiwa (Badan Pusat Statistik, 2019). Hal ini tentu menjadi keuntungan bagi negara Indonesia jika dilihat dari segi kependudukan. Namun semakin besar pertumbuhan penduduk suatu wilayah, masalah yang ditimbulkan juga semakin banyak. Sebagai contoh, dengan adanya pertambahan jumlah penduduk, maka peningkatan sarana dan prasarana penunjang kehidupan seperti perumahan, perkantoran, modal 
transportasi, dan lainnya juga semakin meningkat. Dengan adanya penambahan sarana dan prasarana tersebut, tentu akan berpengaruh terhadap stabilitas lingkungan.

Pengadaan ruang terbuka hijau (RTH) merupakan salah satu upaya dalam menjaga stabilitas lingkungan dalam hal ini ketersediaan udara bersih. Pengembangan RTH tidak saja dilakukan di lingkungan perumahan namun juga di lingkungan pendidikan seperti yang dilakukan di beberapa madrasah di Kota Gorontalo, dan menurut hasil penelitian yang telah dilakukan bahwa sudah ada upaya yang dilakukan namun belum cukup memenuhi kebutuhan RTH ideal sekaligus jumlah pohon yang dibutuhan juga belum terpenuhi, sehingga suplai oksigen yang dihasilkan juga masih rendah (Yusuf et al., 2018). Analisis kebutuhan ruang tebuka hijau diperlukan dalam rangka mengetahui kebutuhan RTH dalam rangka mengoptimalkan pengembangan RTH yang telah ada (Hariani et al., 2014).

Konsep RTH diperlukan pula di lingkungan perumahan sehingga desain rumah yang dibangun setidaknya harus dilengkapi dengan beberapa struktur yang mendukung konsep RTH diantaranya sumur resapan, biopori, bak kontrol, dan taman vertikal (Rurut et al., 2019). Konsep penataan ruang terbuka hijau setidaknya harus mengakomodasi fungsi estetika, fungsi ekonomi, fungsi sosial, dan budaya (Dharmadiatmika, 2017). Peningkatan kualitas hidup juga perlu diperhatikan pada kawasan khusus seperti pemukiman kumuh, dimana pembangunan kawasan ini tidak hanya menghasilkan bangunan layak huni namun juga diperlukan adanya ruang terbuka hijau (Aly et al., 2020). Ketidakseimbangan antara lingkungan terbangun dengan lingkungan pelindung merupakan alasan pentingnya RTH yaitu dalam rangka pengendalian suhu udara yang dapat dilakukan dengan pembangunan hutan kota (Farisi et al., 2017). Selanjutnya perlu dilakukan penilaian persepsi masyarakat terhadap RTH, terkait kenyamanan dan manfaatnya (Atmajayani, 2020). Persepsi yang dimaksud adalah menyangkut aksesbilitas, kondisi pohon, kesejukan, kebersihan, keindahan visual, dan fasilitas.

Pembangunan RTH perlu memperhatikan karakteristikvegetasi tanaman yang ada (Evert etal., 2017). Pada RTH yang sudah ada dilakukan sensus pohon untuk mengetahui karakteristik tanaman terutama hubungannya dalam kemampuan menghasilkan oksigen, menjaga kelembaban dan mengendalikan suhu udara sekitar. Penelitian lain juga dilakukan pengamatan mengenai persepsi pengunjung terhadap kenyamanan hutan kota dalam hal ini adalah tentang kerapatan vegetasi (Sulistyana et al., 2017). Keberadaan hutan kota juga memiliki manfaat visual secara estetik sehingga lanskap tetap dapat dirasakan dan memberikan kesan yang baik (Syahadat \& Putra, 2020).

Semakin meningkatnya jumlah populasi penduduk menyebabkan kebutuhan akan pemukiman juga semakin tinggi, sehingga hal ini harus diimbangi dengan perhitungan atau simulasi mengenai kebutuhan RTH (Ruslan \& Rahmad, 2012). Luasan RTH akan berhubungan dengan perubahan suhu (Ahmad et al., 2012). Analisis luasan hutan kota terhadap penyerapan karbondioksida, penghasil oksigen, dan penyimpanan air tanah perlu dilakukan dalam rangka menjaga kualitas lingkungan dengan kondisi semakin bertambahnya populasi penduduk dan semakin meningkatnya aktivitas manusia (Sriwanita et al., 2017). Biopori merupakan salah satu teknologi ramah lingkungan yang mempunyai tujuan upaya untuk mengatasi banjir (Yohana et al., 2017).

Kepedulian masyarakat terhadap konservasi alam, khususnya lingkungan sekitarnya merupakan salah satu wujud partisipasi masyarakat dalam upaya pelestarian alam (Hidayat, 2017). Kearifan lokal 
ABDIMAS: Jurnal Pengabdian Masyarakat Universitas Merdeka Malang Volume 6, No. 3, August 2021: 404-415

masyarakat merupakan suatu bentuk usaha manusia dalam menggunakan akal budinya dalam bertindak dalam rangka menyikapi suatu peristiwa disekitarnya, dalam hal ini tradisi yang tumbuh di masyarakat juga mempengaruhi pengelolaan lingkungan (Kartikasari et al., 2017). Salah satu ide dalam rangka pelestarian alam lingkungan sekitar adalah dengan merintis kampung tematik yaitu kampung iklim yang salah satu kegiatannya adalah merencanakan teknis pengelolaan air limbah (Sylviana \& Hermana, 2017). Bentuk lainnya dari implementasi konservasi adalah pembuatan taman yang berfungsi sebagai media serapan air (Sudiro, 2008).

Penyebaran pertumbuhan penduduk di Indonesia mengalami ketimpangan antara daerah perkotaan dan pedesaan. Persentase penduduk yang tinggal di daerah perkotaan lebih tinggi daripada daerah pedesaan. Berdasarkan data hasil Sensus Penduduk tahun 2000, Badan Pusat Statistik (BPS) memproyeksikan bahwa pada tahun 2010 jumlah penduduk Indonesia yang tinggal di daerah perkotaan mencapai 54,2\%. Selanjutnya, pada tahun 2025 jumlah tersebut diproyeksikan akan mencapai 68,3\%. Selain karena faktor kelahiran, peningkatan jumlah penduduk daerah perkotaan disebabkan oleh faktor perpindahan atau urbanisasi.

Peningkatan jumlah penduduk daerah perkotaan yang lebih besar dari daerah pedesaan akan menjadikan daerah perkotaan mengalami kepadatan penduduk. Dampak kepadatan penduduk daerah perkotaan terhadap lingkungan adalah polusi udara yang meningkat dan minimnya lahan atau kawasan hijau akibat peningkatan pembangunan. Kota Malang merupakan salah satu daerah perkotaan yang menjadi dampak dari permasalahan pertumbuhan penduduk terhadap lingkungan. Salah satu indikator pencemaran lingkungan di Kota Malang yaitu pencemaran udara. Berdasarkan data Dinas Kesehatan Kota Malang (DINKES) tahun 2018, angka penderita infeksi saluran pernapasan akut (ISPA) menempati urutan pertama di Kota Malang dengan jumlah kasus mencapai 78.457 selama tahun 2018. Menurut Organisasi Kesehatan Dunia (World Health Organization/WHO) ISPA merupakan penyakit yang sering terjadi di masyarakat. Terdapat 156 juta episode baru kejadian ISPA di dunia per tahun dimana 151 juta episode $(96,7 \%)$ terjadi di negara berkembang. ISPA lebih sering terjadi pada anak-anak, dengan insiden kelompok umur balita diperkirakan 0,29 episode per anak per tahun di negara berkembang dan 0,05 episode per anak per tahun di negara maju.

Wilayah dengan jumlah penderita ISPA tertinggi di Kota Malang diantaranya Kedungkandang, Pandanwangi, dan Mulyorejo dengan mayoritas penderitanya adalah balita. Jika tidak ditangani dengan tepat penyakit ini dapat mengakibatkan kematian pada penderita. Saat ini, penanggulangan penyakit ISPA di Kota Malang masih difokuskan pada upaya penemuan secara dini (Dinas Kesehatan Kota Malang, 2018). Namun untuk upaya pencegahannya sendiri masih belum dilakukan, sehingga penyakit ISPA akan terus menimbulkan korban yang lainnya. Oleh karena itu solusi untuk mengatasi masalah lingkungan tersebut dengan menerapkan pembangunan yang berwawasan lingkungan atau berkelanjutan (Sustainable Development).

Menurut Perserikatan Bangsa-Bangsa (PBB) Pembangunan berkelanjutan (sustainable development) adalah pembangunan yang bertujuan meningkatkan kualitas hidup orang di seluruh dunia, baik dari generasi sekarang maupun yang akan datang, tanpa mengeksploitasi penggunaan sumber daya alam yang melebihi kapasitas dan daya dukung bumi. Tujuan tersebut bisa dicapai melalui empat elemen 
tujuan pembangunan berkelanjutan: (1) Pertumbuhan dan keadilan ekonomi; (2); Pembangunan sosial; (3) Konservasi sumberdaya alam (perlindungan lingkungan); (4) Pemerintahan yang baik (good governance). Keempat elemen tersebut saling mendukung satu dengan lainnya, menciptakan tujuan pembangunan yang berkaitan dan berkelanjutan.

Kawasan perancangan kampung oksigen dilakukan di Kelurahan Pandanwangi yang merupakan salah satu kelurahan yang ada di Kecamatan Blimbing, Kota Malang. Kelurahan Pandanwangi berjarak sekitar 2 km dari pusat Pemerintahan Kecamatan Blimbing atau sekitar 7 km dari gedung Balaikota Kota Malang. Kelurahan Pandanwangi merupakan salah satu dari kelurahan yang ada di Kota Malang dengan jumlah penderita penyakit ISPA yang tertinggi. Hal ini duduga salah satunya adalah karena kualitas udara di Kelurahan Pandanwangi tergolong kurang baik, dalam hal ini adalah adanya kemungkinan kurangnya kadar oksigen di udara. Adapun beberapa penyebab pencemaran udara di Kelurahan Pandawangi adalah letak kelurahan yang berada pada posisi strategis dari atau ke pusat kota, sehingga intensitas arus lalu lintas di daerah tersebut menjadi tinggi. Selain itu, minimnya kawasan hijau sebagai penyerap karbondioksida yang dihasilkan oleh aktivitas kendaraan. Hal lain yang menjadi penyebab kurangnya kadar oksigen di udara menurut pengamatan umum tim pengabdi adalah kurangnya aktivitas penanaman tanaman hijau di lingkungan mitra yang artinya bahwa kesadaran masyarakat akan pentingnya menanam tanaman hijau sebagai salah satu upaya menjaga ketersediaan oksigen di udara. Sehingga berdasarkan uraian permasalahan mitra di atas, tim pelaksana program bersama dengan mahasiswa teknik sipil memberikan solusi dengan melakukan perancangan berupa Kampung Oksigen.

Lingkungan yang berwawasan lingkungan merupakan konsep yang mendukung perwujudan pembangunan yang berkelanjutan sehingga tim pengabdi yang selain beranggotakan dosen lintas jurusan juga melibatkan mahasiswa secara langsung menggagas kampung oksigen sebagai upaya mengatasi permasalahan lingkungan di Kelurahan Pandanwangi. Hal ini dilakukan dengan tujuan untuk mencegah sumber penyakit ISPA di kelurahan tersebut. Wujud kampung oksigen yang direncanakan adalah dengan memperbanyak tanaman yang mempunyai kemampuan menyerap karbondioksida dan menghasilkan oksigen. Mempertimbangkan hal tersebut, disepakati jenis vegetasi yang akan ditanam adalah Sansevieria dan anggur. Tanaman Sansevieria atau juga dikenal dengan nama lidah mertua memiliki manfaat menyerap karbondioksida dan tentu saja kekhasan tanaman hijau juga yaitu menghasilkan oksigen. Secara estetika, tanaman lidah mertua juga merupakan jenis tanaman pagar dan mempunyai kelebihan mudah dikembangbiakkan, mudah dalam perawatan serta tahan terhadap perubahan cuaca. Jenis tanaman lain yang digunakan yaitu anggur, dengan pertimbangan bahwa tanaman rambat ini selain secara estetika dapat menghiasi Gapura Kampung Oksigen yang akan didirikan bahwa tanaman anggur ini menghasilkan buah yang dapat diambil manfaatnya oleh masyarakat. Salah satu warga yang merupakan bagian kelompok mitra sebelum adanya program pengabdian ini juga telah mencoba menanam anggur di sekitar rumahnya dan terbukti hasilnya berbuah dengan baik sehingga warga yang lain menginginkan untuk dapat menanam tanaman anggur di lingkungan rumahnya. Keterlibatan aktif kelompok mitra merupakan hal penting di dalam proses pelaksanaan pengabdian, sehingga ide dan saran dari kelompok mitra menjadi salah satu pertimbangan penetapan jenis program dalam pengabdian kepada masyarakat. Oleh karena itu, partisipasi masyarakat Kelurahan Pandanwangi sangat dibutuhkan dalam pelaksanaan pembangunan kampung oksigen sehingga keberlanjutannya dapat terwujud. 
ABDIMAS: Jurnal Pengabdian Masyarakat Universitas Merdeka Malang Volume 6, No. 3, August 2021: 404-415

Tujuan dari kegiatan pengabdian ini adalah mewujudkan pembangunan yang berkelanjutan berdasarkan uraian permasalahan di atas, tim yang terdiri dari dosen Jurusan Teknik Industri, dosen dan mahasiswa Jurusan Teknik Sipil serta dosen Jurusan Ekonomi Pembangunan Universitas Merdeka Malang menggagas kampung oksigen sebagai upaya mengatasi permasalahan lingkungan di Kelurahan Pandanwangi. Hal ini dilakukan dengan tujuan untuk mencegah sumber penyakit ISPA di kelurahan tersebut. Wujud kampung oksigen adalah dengan memperbanyak tanamanyang mempunyai kemampuan menyerap karbondioksida dan menghasilkan oksigen. Oleh karena itu, partisipasi masyarakat Kelurahan Pandanwangi sangat dibutuhkan dalam pelaksanaan pembangunan kampung oksigen sehingga terpelihara dengan benar dan baik.

\section{METODE}

Metode pelaksanaan kegiatan pengabdian ini menjelaskan mengenai tahapan pelaksanaan pekerjaan yang akan dilakukan dan terdiri dari beberapa tahap.

\section{Penyusunan dan persetujuan rencana kegiatan}

Tahapan yang dilakukan dalam pelaksanaan pekerjaan ini adalah menyusun perencanaan kegiatan Kampung Oksigen. Keseluruhan jumlah tim inti kegiatan berjumlah 10 orang terdiri atas 3 orang dosen, 5 orang mahasiswa dan 2 orang perwakilan dari mitra kelompok masyarakat Pandanwangi, namun pada pelaksanaannya mitra memberikan dukungan penuh partisipasi aktif masyarakat Pandanwangi terutama terkait pengerjaan infrastruktur. Penguatan tim pelaksana program juga dilakukan pada tahap ini yaitu dengan melibatkan mahasiswa secara langsung mulai dari persiapan, koordinasi dengan mitra sampai nanti pada tahap pelaksaan di lapang. Mahasiswa yang terlibat berasal dari prodi S1 teknik sipil yang dalam pelaksanaan program ini nantinya tidak hanya terlibat pada kegiatan lapang namun juga sampai pada target output luaran yang akan dihasilkan.

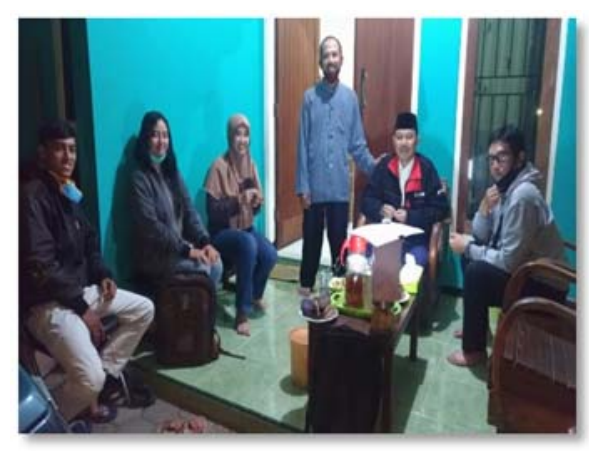

Gambar 1. Koordinasi tim pengabdian

Koordinasi tim pengabdian dilakukan secara intens antara dosen, mahasiswa, dan perwakilan mitra baik secara langsung seperti pada Gambar 1, maupun memanfaatkan media komunikasi elektronik. Sebelum penyusunan rencana kegiatan, telah dilakukan empat kali survei baik ke lokasi program maupun 
ke pihak terkait dalam upaya memenuhi data pendukung. Mahasiswa secara aktif melakukan survei lapang, bertemu langsung dengan mitra dan pihak terkait seperti aparatur kelurahan, tokoh masyarakat, kelompok masyarakat.

\section{Pekerjaan persiapan}

Persiapan dilakukan dengan empat tahap, yaitu: (1) Sosialisasi ke masyarakat. Tahapan yang dilakukan dalam pelaksanaan pekerjaan ini adalah mengadakan sosialisasi kepada masyarakat khususnya masyarakat Kelurahan Pandanwangi RT 05 RW 14 tentang tentang pelaksanaan serta metode perawatan tanaman. Pada tahap ini mahasiswa akan melakukan sosialisasi langsung kepada masyarakat didampingi oleh dosen pembimbing program; (2) Survei Lokasi, bahan, dan material. Tahapan yang dilakukan adalah melakukan survei lokasi yang akan dilaksanakan. Selain lokasi, pekerjaan survei juga dilakukan untuk mencari alat dan bahan yang digunakan pada saat pelaksanaan; (3) Pembersihan Lokasi. Tahapan yang dilakukan ini adalah melakukan pembersihan lokasi kegiatan agar tidak ada kendala pada saat pelaksanaan; (4) Mobilisasi alat dan bahan. Tahapan yang dilakukan ini adalah mobilisasi peralatan dan bahan yang akan digunakan pada saat pelaksanaan kegiatan seperti alat las, besi hollow, pot bunga, tanah, pupuk serta peralatan dan bahan yang lainnya.

\section{Pelaksanaan kegiatan}

Tahapan yang dilakukan dalam pelaksanaan pekerjaan ini adalah pemasangan gapura di depan gang pondok pesantren dan penanaman bunga krisan dan lainnya.

\section{Penyusunan laporan \& evaluasi kegiatan}

Pada tahapan kegiatan ini yang dilakukan adalah menyusun laporan kegiatan serta melakukan evaluasi kegiatan.

\section{Kegiatan perawatan tanaman}

Pada tahapan kegiatan ini yang dilakukan adalah merawat tanaman yang sudah ditanam dengan memperhatikan nutrisi yang dibutuhkan tanaman sehingga tanaman dapat tumbuh dan berkembang dengan baik.

\section{HASIL DAN PEMBAHASAN}

Sesuai dengan target luaran yang dicapai sebagai wujud solusi atas permasalahan mitra diantaranya adalah adanya peningkatan kesadaran masyarakat terhadap pentingnya kualitas lingkungan. Adapun hasil yang telah dilaksanakan pada kegiatan pengabdian ini.

\section{Pembuatan gapura}

Gapura merupakan simbol dari perwujudan "Kampung Oksigen" yang dirintis oleh tim pengabdi. Fungsi utama dari gapura ini sendiri adalah sebagai penopang untuk tumbuhnya tanaman. Pembangunan 
ABDIMAS: Jurnal Pengabdian Masyarakat Universitas Merdeka Malang Volume 6, No. 3, August 2021: 404-415

gapura dilaksanakan secara bersama-sama antara mitra bersama kelompok masyarakat dengan tim pengabdi. Materi yang digunakan untuk gapura adalah besi hollow dengan ukuran yang telah disesuaikan dengan kebutuhan dan mempertimbangan bahwa materi ini awet, perawatannya mudah, dan secara estetik juga cukup indah.

Pemilihan infrastruktur gapura dalam program pengabdian dikarenakan menyesuaikan dengan potensi lingkungan mitra, dimana lokasi dibangunnya gapura merupakan tempat yang secara rutin setiap hari minggu dikunjungi masyarakat umum untuk kegiatan ibadah (pengajian). Sehingga target dari program kampung oksigen ini nantinya tidak hanya berdampak bagi masyarakat sekitar Pandanwangi, namun juga dapat dirasakan dan bahkan dapat menjadi inspirasi bagi masyarakat umum untuk lebih peduli terhadap lingkungan khususnya kualitas oksigen di udara.

Lokasi pendirian gapura berada di pinggir jalan yang merupakan pintu masuk dari sebuah pondok pesantren. Pada Gambar 2 terlihat suasana (sebelum masa pandemik COVID-19) dimana pada setiap hari minggu, disekitar lokasi tersebut diselenggarakan kegiatan keagamaan yang dihadiri ratusan orang dari berbagai kawasan sekitar. Hal ini menjadi salah satu pertimbangan penempatan gapura Kampung Oksigen sehingga akan semakin banyak orang terinspirasi untuk sadar diri pentingnya menjaga kelestarian lingkungan terutama ketersediaan oksigen.

Pada Gambar 3 ditunjukkan lokasi tepatnya gapura penanda Kampung Oksigen akan dipasang, yaitu tepat di jalan masuk menuju pesantren yang terdapat di lokasi pengabdian. Selanjutnya desain gapura yang telah dirancang sesuai dengan lokasi penempatan segera dibuat. Pembuatan gapura tersebut dilakukan di bengkel pembuatan secara perbagian sehingga memudahkan dalam pemasangan di lokasi.
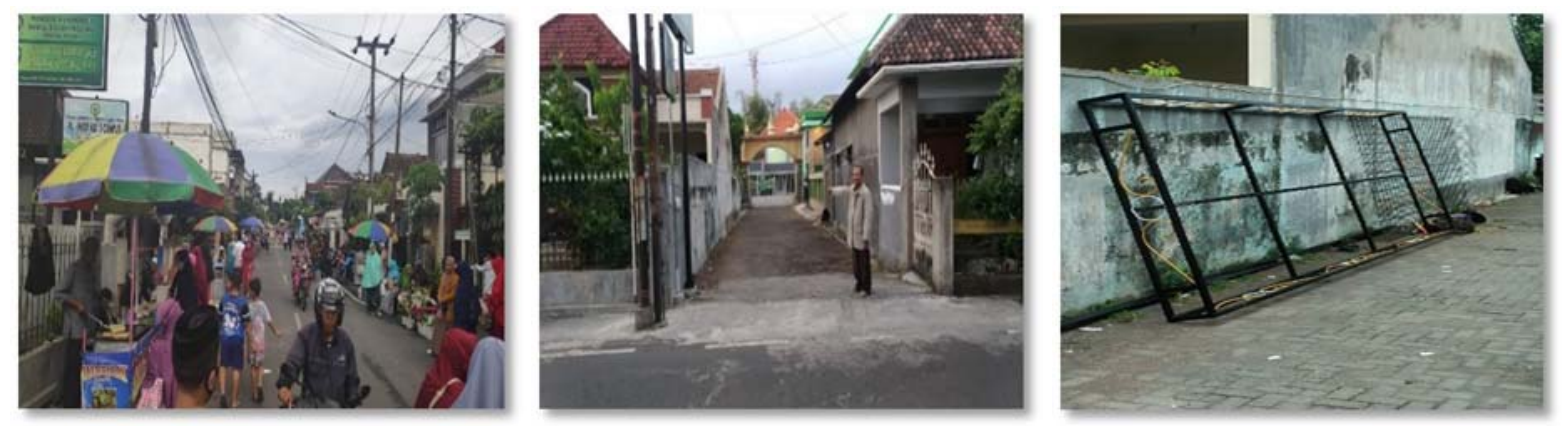

Gambar 2. Suasana sekitar penempatan gapura

Gambar 3. Lokasi penempatan gapura

Gambar 4. Desain bagian atas gapura

Desain gapura pada Gambar 4 dibuat dari bahan material besi dengan alasan lebih fleksibel dalam merancang bentuknya, biaya pemasangan yang terjangkau, waktu pengerjaan lebih cepat dan sesuai dengan konsep kegiatan. Gapura berupa pergola besi ini merupakan rancangan dari mahasiswa teknik sipil dengan beberapa masukan saran penyempurnaan dari dosen serta mitra yang disesuaikan juga dengan kondisi lingkungan sekitar serta budaya kebiasaan masyarakat setempat. 
Gagasan Kampung Oksigen Pandanwangi sebagai Upaya Meningkatkan Kesadaran Masyarakat Peduli Lingkungan... Aris Siswati, Dani Yuniawan

\section{Pemasangan gapura}

Pelaksanaan pemasangan gapura dilaksanakan setelah pembuatan yang dilakukan di bengkel las selesai dilakukan. Pemasangan perbagian gapura dilakukan dengan teliti sehingga akan menghasilkan gapura seperti yang telah dirancang sebelumnya. Pada Gambar 5 merupakan proses pengerjaan dan pemasangan gapura.
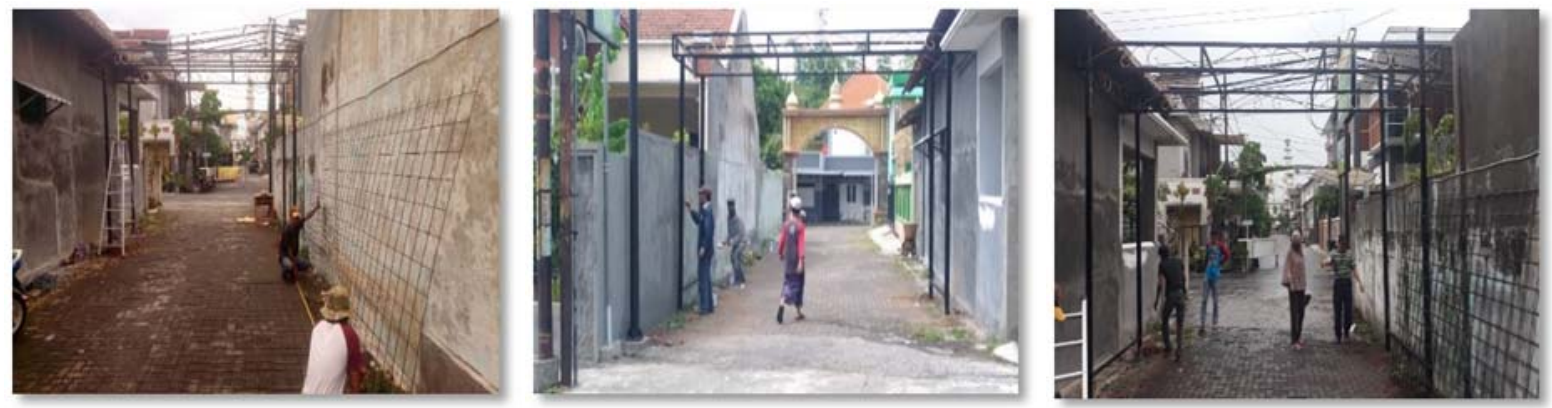

Gambar 5. Proses pengerjaan pemasangan gapura

Proses pemasangan gapura ini memerlukan waktu selama 2 hari dikarenakan kendala hujan yang terjadi pada saat pemasangan sehingga pekerjaan dilanjutkan pada hari berikutnya. Materi yang digunakan untuk gapura adalah besi hollow dan dilapisi pernis dan cat sehingga secara visual terlihat lebih indah dan diharapkan akan lebih tahan cuaca luar ruangan.

\section{Penanaman vegetasi}

Jenis vegetasi yang dipilih untuk kegiatan Kampung Oksigen ini adalah tanaman anggur dan Sansevieria. Kedua tanaman tersebut dipilih dengan alasan bahwa tanaman anggur merupakan tanaman rambat yang secara estetik terlihat indah sebagai penghias gapura dan di sisi lain tanaman ini menghasilkan buah yang dapat dimanfaatkan oleh masyarakat. Tanaman kedua yang dipilih adalah Sansevieria, dengan alasan bahwa tanaman ini merupakan jenis tanaman yang relatif tahan sebagai tanaman luar ruangan, pengembangbiakan serta perawatannya mudah, dan tentu saja juga memenuhi fungsi estetik sebagai tanaman hias. Selain itu tanaman Sansevieria juga memiliki manfaat menghasilkan oksigen yang bermanfaat bagi lingkungan sekitar. Kegiatan penanaman ditunjukkan pada Gambar 6 .
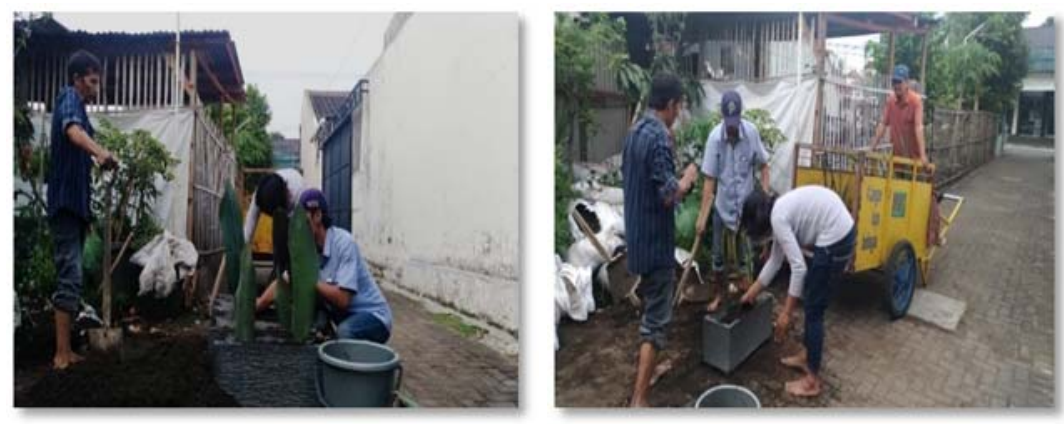

Gambar 6. Penanaman Sansevieria 
ABDIMAS: Jurnal Pengabdian Masyarakat Universitas Merdeka Malang Volume 6, No. 3, August 2021: 404-415

Penanaman kedua jenis vegetasi seperti pada Gambar 6 dilaksanakan secara bersama-sama antara tim pengabdi dengan masyarakat di lokasi pengabdian. Hal ini dalam rangka menumbuhkan kesadaran masyarakat pentingnya keberadaan kampung oksigen yang dirintis, sehingga timbul rasa tanggung jawab masyarakat untuk turut serta menjaga lingkungannya.
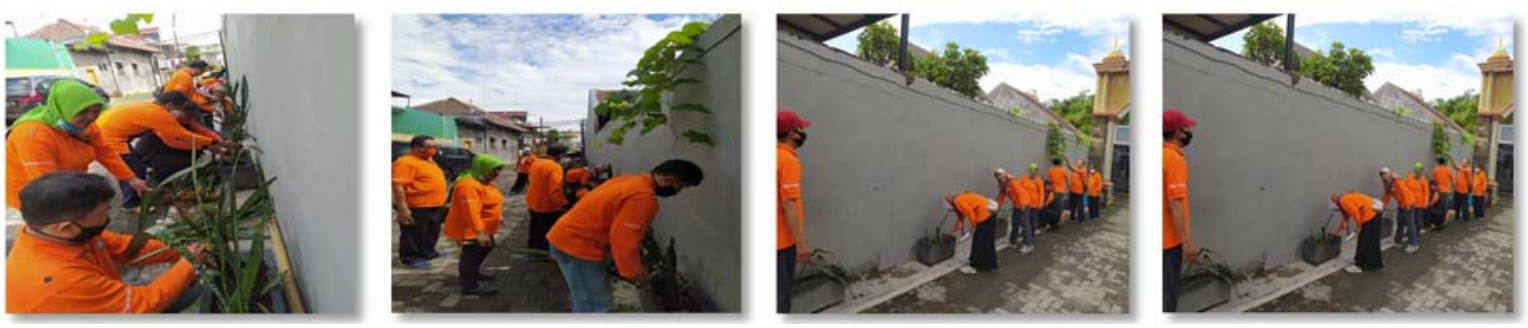

Gambar 7. Partisipasi mitra kelompok masyarakat dalam proses kegiatan pengabdian

Partisipasi masyarakat pada kegiatan pengabdian merupakan wujud nyata bahwa kegiatan pengabdian dilaksanakan atas dasar kebutuhan masyarakat. Sinergi positif terbentuk diantara masyarakat dengan akademisi sehingga kedua pihak akan mendapatkan manfaat yang cukup baik dari kegiatan bersama yang dilaksanakan.

Gapura Kampung Oksigen merupakan hasil jadi dari pelaksanaan kegiatan pengabdian yang merupakan bentuk inisiasi awal dalam rangka memberikan edukasi secara tidak langsung kepada masyarakat mengenai pentingnya keterlibatan masyarakat dalam menjaga kelestarian lingkungan terutama ketersediaan oksigen di udara. Selain gapura Kampung Oksigen, disekitar lokasi pendirian juga terdapat pot yang berisi tanaman Sansiviera (lidah mertua). Pada sisi-sisi Gapura Kampung Oksigen ini telah diisi dengan tanaman anggur dan selanjutnya akan terus dirawat oleh masyarakat.
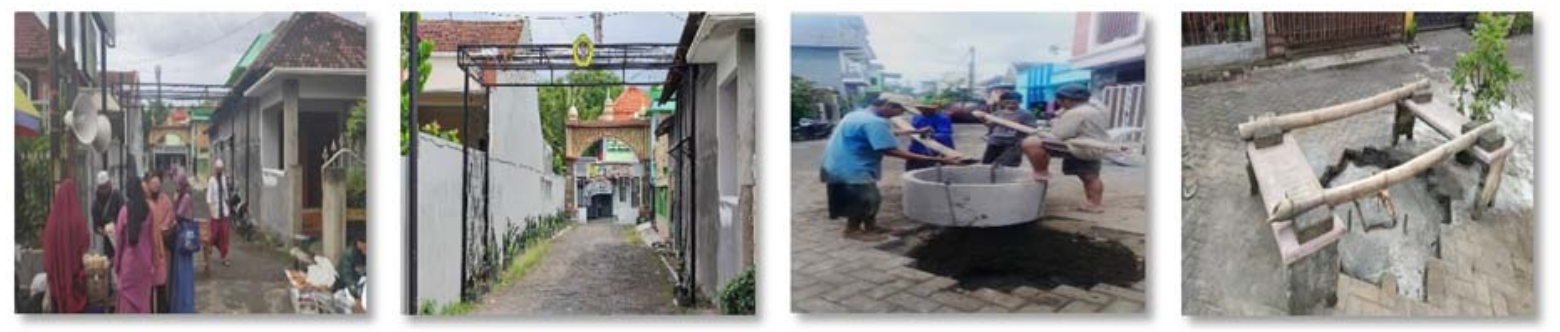

Gambar 8. Gapura Kampung Oksigen

Gambar 9. Sumur resapan

Dukungan infrastruktur lain pada kegiatan pengabdian ini adalah pembangunan sumur resapan yang merupakan hasil kolaborasi dengan dosen dari Jurusan Teknik Sipil. Desain dari sumur resapan diharapkan menjadi inspirasi bagi masyarakat bagaimana teknik membuat sumur resapan yang lebih ekonomis namun tidak mengubah fungsi utamanya menampung air hujan sehingga mengurangi resiko terjadinya genangan air permukaan ketika hujan dan menjadi penampung air cadangan pada musim kemarau. 


\section{Gagasan Kampung Oksigen Pandanwangi sebagai Upaya Meningkatkan Kesadaran Masyarakat Peduli Lingkungan... Aris Siswati, Dani Yuniawan}

Perubahan sikap dan pengetahuan masyarakat dalam hal ini mitra merupakan hasil utama yang diharapkan dalam kegiatan pengabdian. Oleh karena ini hendaknya komunikasi tim pengabdi dengan mitra tidak terhenti tepat pada saat kegiatan berakhir namun akan berlanjut sehingga keberlanjutan perubahan sikap yang diharapkan dapat terwujud yaitu masyarakat yang secara sadar dan mandiri menunjukkan perilaku sadar lingkungan untuk turut serta menjaga kebersihan udara. Perubahan pengetahuan masyarakat yang dapat terlihat pada kegiatan pengabdian ini adalah bertambahnya wawasan masyarakat mengenai jenis tanaman yang memiliki manfaat meningkatkan kadar oksigen di udara serta cara pengembangbiakan serta perawatannya. Perubahan sikap secara langsung yang terwujud pada pengabdian ini dapat diukur melalui keterlibatan masyarakat dalam pelaksanaan kegiatan, dimana masyarakat berperan aktif baik secara fisik maupun ide dalam mewujudkan target program.

Secara keseluruhan kegiatan-kegiatan yang telah direncanakan pada kegiatan pengabdian ini telah terlaksana dengan dukungan penuh dari mitra, partisipasi aktif dari masyarakat Pandanwangi mulai dari perencanaan sampai dengan pelaksanaan. Beberapa kendala sempat terjadi pada saat pelaksanaan kegiatan yang dilaksanakan pada masa Pandemi COVID-19, namun berkat kerjasama tim yang solid kendala tersebut dapat diatasi dengan baik.

\section{SIMPULAN DAN SARAN}

Kegiatan pengabdian kepada masyarakat yang dilaksanakan oleh tim pengabdi dari Universitas Merdeka Malang (Unmer Malang) ini merupakan salah satu program pengabdian internal yang dinamakan Unmer Membangun Desa. Tujuan utama dari kegiatan ini adalah sebagai upaya implementasi hasil pemikiran akademisi kepada masyarakat secara langsung, dalam hal ini tim pengabdi menyikapi salah satu fenomena berupa isu lingkungan di masyarakat khususnya mitra yaitu masyarakat Pandanwangi, Kota Malang. Target yang hendak dicapai dalam program ini adalah mitra, yaitu masyarakat Pandanwangi memiliki kesadaran yang lebih baik untuk menjaga lingkungan sekitar terutama kepedulian terhadap ketersediaan oksigen yang merupakan kebutuhan utama manusia. Pelaksanaan kegiatan pada pengabdian ini dibagi dalam beberapa tahap yang pada setiap tahapnya melibatkan langsung mitra pengabdi dalam pelaksanaannya. Hasil fisik dari kegiatan pengabdian ini berupa pembangunan dan pemenuhan infrastruktur yang menjadi inisiasi memupuk kesadaran masyarakat untuk peduli lingkungan, yaitu Gapura Kampung Oksigen yang akan dilengkapi dengan tanaman rambat berupa tanaman anggur, pot tanaman Sansivera di sekitar lokasi gapura dan pembangunan sumur resapan. Diharapkan dengan pembangunan beberapa infrastruktur tersebut, mitra masyarakat Pandanwangi turut berperan dalam menjaga lingkungannya dengan mengembangbiakkan tanaman yang sudah ada dan kedepan tanaman tersebut dapat menjadi potensi usaha bagi masyarakat.

Keterbatasan dalam kegiatan pengabdian masyarakat ini adalah mengenai penyesuaian waktu pelaksanaan setiap kegiatan mengingat aktivitas kelompok mitra yang sebagian besar berprofesi di sektor formal sehingga beberapa program yang telah dijadwalkan sempat tertunda pelaksanaannya. Selain itu adanya kondisi pandemi COVID-19 yang terjadi juga menimbulkan kendala lapang dimana interaksi tim pengabdi dan mitra juga menjadi terbatas. Saran yang perlu dipertimbangkan untuk keberlanjutan hasil yang telah dicapai adalah perlu adanya pendampingan berlanjut setelah pelaksanaan 
ABDIMAS: Jurnal Pengabdian Masyarakat Universitas Merdeka Malang Volume 6, No. 3, August 2021: 404-415

program pengabdian ini dalam rangka untuk terus menjalin kerjasama dengan mitra sehingga hasil dari pelaksanaan kegiatan akan terus bermanfaat misalnya pemberian wawasan pengolahan hasil tanaman yang telah dibudidayakan baik anggur maupun Sansevieria. Selain itu komunikasi dalam bentuk pemberian motivasi juga perlu tetap dilakukan sehingga masyarakat akan tetap konsisten melaksanakan komitmennya untuk turut serta menjaga kelestarian lingkungan.

\section{UCAPAN TERIMA KASIH}

Tim pengabdi menyampaikan ucapan terima kasih kepada Universitas Merdeka Malang yang telah memberikan dukungan penuh pada program ini, sehingga seluruh kegiatan dapat terselenggara dan memberikan manfaat bagi masyarakat. Harapan dari tim pengabdi dan masyarakat bahwa kegiatan sejenis dapat kembali diselenggarakan sehingga masyarakat merasakan secara langsung manfaat keberadaan kalangan akademisi bagi lingkungan.

\section{DAFTAR PUSTAKA}

Ahmad, F., Arifin, H. S., Dahlan, E. N., Effendy, S., \& Kurniawan, R. (2012). Analisis hubungan luas ruang terbuka hijau (RTH) dan perubahan suhu di Kota Palu. Jurnal Hutan Tropis, 13(2), 173-180.

Aly, S. H., Hustim, M., Selintung, M., Zakaria, R., Djamaluddin, I., \& Putry, N. A. N. (2020). Sosialisasi dan perencanaan konsep green ruang terbuka hijau (RTH) pada pemukiman kumuh di Kelurahan Mario Kota Makassar. Jurnal Tepat: Applied Technology Journal for Community Engagement and Services, 3(1), 58-70. https://doi.org/10.25042/jurnal_tepat.v3i1.101

Atmajayani, R. D. (2020). Hutan kota dalam kajian tingkat kenyamanan bagi masyarakat (Studi kasus Hutan Kota Blitar). Briliant: Jurnal Riset dan Konseptual, 5(3), 627-635.

http://dx.doi.org/10.28926/briliant.v5i3.503

Badan Pusat Statistik. (2019). Statistik Indonesia 2019. Jakarta: Badan Pusat Statistik.

Dharmadiatmika, I. M. A. (2017). Konsep penataan ruang terbuka hijau publik di Kota Kecamatan Mengwi, Kabupaten Badung, Provinsi Bali. E-Jurnal Arsitektur Lansekap, 3(2), 213-222.

Dinas Kesehatan Kota Malang. (2018). Profil Kesehatan Kota Malang Tahun 2017. Malang: Dinas Kesehatan.

Evert, A., Yuwono, S. B., \& Duryat, D. (2017). Tingkat kenyamanan di Hutan Kota Patriot Bina Bangsa Kota Bekasi. Jurnal Sylva Lestari, 5(1), 14-25. http://dx.doi.org/10.23960/jsl1514-25

Farisi, S. A., Ramdlani, S., \& Haripradianto, T. (2017). Pengoptimalan fungsi ruang terbuka hijau pada komplek Hutan Kota Velodrom Sawojajar. Jurnal Mahasiswa Jurusan Arsitektur Universitas Brawijaya, 5(2).

Hariani, M. L., Astor, Y., \& Anwar, S. (2014). Analisis pengembangan potensi ruang terbuka hijau (RTH) di Kota Cirebon. Jurnal Konstruksi.

Hidayat, N. H. (2017). Pengaruh program konservasi hutan kota oleh (pemerintah dan swasta) dan kepedulian masyarakat terhadap konservasi hutan kota (2013). Jurnal Green Growth dan Manajemen Lingkungan, 6(2), 16-31. https://doi.org/10.21009/jgg.062.02 
Gagasan Kampung Oksigen Pandanwangi sebagai Upaya Meningkatkan Kesadaran Masyarakat Peduli Lingkungan... Aris Siswati, Dani Yuniawan

Kartikasari, D., Oramahi, H. A., \& Idham, M. (2017). Kearifan lokal masyarakat Kelurahan Pasiran dalam pengelolaan hutan kota Gunung Sari kota Singkawang. Jurnal Hutan Lestari, 5(2), 375-381. http://dx.doi.org/10.26418/jhl.v5i2.19984

Rurut, R. Y., Rachmawati, P. F., Narasi, N. K., Rogahang, R. J., Supit, S., \& Sari, D. P. (2019). Tinjauan perencanaan fasilitas penunjang ruang terbuka hijau (RTH) di Perumahan Relokasi Pandu Kota Manado. Jurnal Teknik Sipil Terapan, 1(1), 17-28. http://dx.doi.org/10.47600/jtst.v1i1.221

Ruslan, M., \& Rahmad, B. (2012). Kajian ruang terbuka hijau dalam rangka pembentukan hutan kota di Banjarbaru. Jurnal Hutan Tropis, 13(1), 73-91. http://dx.doi.org/10.20527/jht.v13i1.1497

Sriwanita, C., Mubarak, M., \& Nurhidayah, T. (2017). Analisis luasan hutan kota berdasarkan kemampuan menyerap CO2, kebutuhan O2 dan kebutuhan air di Kota Pekanbaru. Dinamika Lingkungan Indonesia, 4(2), 75-85. http://dx.doi.org/10.31258/dli.4.2.p.75-85

Sudiro, S. (2008). Pengelolaan kualitas udara sektor transportasi: Analisis kasus beberapa kota di dunia. Jurnal Spectra, 12(6), 1-13.

Sulistyana, M. I. C. D., Yuwono, S. B., \& Rusita, R. (2017). Kenyamanan Hutan Kota Linara berbasis kerapatan vegetasi, iklim mikro dan persepsi masyarakat di Kota Metro. Jurnal Sylva Lestari, 5(2), 78-87. http://dx.doi.org/10.23960/js|2578-87

Syahadat, R. M., \& Putra, P. T. (2020). Manfaat visual keberadaan hutan kota Padang Golf Halim. Jurnal Arsitektur Lansekap, 6(1), 107. https://doi.org/10.24843/JAL.2020.v06.i01.p12

Sylviana, R., \& Hermana, D. (2017). Perencanaan teknis pengelolaan air limbah sebagai salah satu implementasi program kampung iklim. Bentang, 5(2), 154-166.

Yohana, C., Griandini, D., \& Muzambeq, S. (2017). Penerapan pembuatan teknik lubang biopori resapan sebagai upaya pengendalian banjir. Jurnal Pemberdayaan Masyarakat Madani (JPMM), 1(2), 296-308. https://doi.org/10.21009/JPMM.001.2.10

Yusuf, N., Wunarlan, I., \& Rizqi, S. A. (2018). Madrasah hijau menuju kota hijau. Jurnal Teknik, 16(2), 73-84. 